Pregledni znanstveni rad

DOI: $10.17234 /$ Croatica.42.18

UDK: $811.163 .42: 801.6$

811.163.42’36Mažuranić, A.

Primljen: 27. XI. 2017.

Prihvaćen: 28. I. 2018.

\title{
NAGLASNA TEORIJA ANTUNA MAŽURANIĆA
}

\author{
Helena Delaš \\ Filozofski fakultet Sveučilišta u Zagrebu \\ Odsjek za kroatistiku \\ helena.delas@vk.t-com.hr
}

U radu se istražuje na koji je način novoštokavski naglasni sustav opisan u starijoj hrvatskoj gramatici objavljenoj prije devedesetih godina 19. stoljeća i nametanja Karadžić-Daničićeva prozodijskog sustava kako bi se poduprlo suvremeno hrvatsko standardno naglašavanje. Mažuranićeva Slovnica prvi je veći opis novoštokavskoga naglasnog sustava u nas i okosnica Mažuranićeva akcentološkog rada u kojem je iznesena moderna naglasna teorija utemeljena na čvrstom odnosu između čakavske i štokavske akcentuacije u dubinskoj strukturi što ujedno pokazuje da se Mažuranićeva koncepcija hrvatskoga standardnog jezika bitno razlikovala od vukovske standardnojezične koncepcije.

Ključne riječi: hrvatska akcentuacija, Antun Mažuranić, gramatika, hrvatski standardni jezik

\section{UVOD}

Jedan od mogućih putova proučavanja standardizacije hrvatskoga jezika svakako je propitivanje novoštokavskih naglasnih modela u starim hrvatskim gramatikama kako bi se uspostavio kontinuitet hrvatskoga normativnoakcentološkog djelovanja prekinutog devedesetih godina 19. stoljeća nametanjem Karadžić-Daničićeva prozodijskog sustava. Pojava Slovnice 
Hèrvatske Antuna Mažuranića 1859. godine u tom je smislu važna karika. Mažuranićeva je gramatika izišla u godini prije pada Bachova apsolutizma, bila je namijenjena đacima gimnazija i realnih škola, a s obzirom na to da je zamišljena kao prvi dio gramatike (Dio I. Réčoslovje.), u središtu gramatičkoga opisa su glasovi i oblici hrvatskoga jezika. Nadopunjuje ju Veberova sintaksa (Skladnja ilirskoga jezika, za niže gimnazije, Beč, 1859) čime smo dobili "prvi zaokružen gramatički opis hrvatskoga jezika u skladu s visokim mjerilima gramatičkoga umijeća novoga vremena" (Katičić 2008: 7, u: Mažuranić 2008 [Pretisak prvog izdanja, 1859]). U deset godina objavljena su čak četiri izdanja Mažuranićeve Slovnice (1859, 1861, 1866. i 1869), što najbolje govori o njezinoj kvaliteti, a u ovom se radu analizira drugo izdanje iz 1861, u kojem se ponavlja tekst Predgovora k pèrvomu izdanju. Naglasnoj teoriji iznesenoj u Slovnici Hèrvatskoj svojevrstan je nastavak Mažuranićeva znanstvena rasprava $O$ važnosti accenta hèrvatskoga za historiu Slavjanah iz 1860. u kojoj usporedbom čakavskoga naglaska s ruskim dokazuje važnost hrvatske prozodije za slavistiku. Mažuranić je Slovnicu sastavio po svojim Temeljima ilirskoga i latinskoga jezika za početnike (1839[1], 1842[2]), pisanih kontrastivnom metodom, dodavši nauk o accentu po hercegovačkom izgovoru i tvorenje rěčih. Međutim onovremeni velik ugled i utjecaj Karadžićev nije značio nekritičko preuzimanje Karadžićeva tipa štokavskoga narodnog govora jer je Mažuranić, kao izvorni govornik vinodolske čakavštine, utvrdio čvrst odnos između štokavskoga i čakavskoga naglaska. Metodološki postupak kojim se povezanost čakavske i štokavske akcentuacije u dubinskoj strukturi pretpostavlja naglasnoj bliskosti po razvojnome stupnju heterogenih novoštokavskih govora jasno pokazuje da se Mažuranićevo gledanje na osnovicu standardnoga jezika kao nadregionalnoga idioma nije podudaralo s Karadžićevim. Kako je u Prilogu poznavanju akcenatske teorije Mažuranićeve napisao J. Gopić (1907: 5): "Jedinstvenost je akcenatska najbolji dokaz za jedinstvenost jezičnu, a u tome leži i rješenje za samo ime jezično." Naziv jezika koji gramatika opisuje je hrvatski. Mogao bi se taj jezik, kaže Mažuranić, u nepostojanju jednoga općeg narodnog imena prema Kopitaru zvati hrvatsko-srpskim ili srpsko-hrvatskim, mnogi ga književnici zovu nekadašnjim zemljopisnim imenom ilirskim, a on se odlučio za narodno ime koje je jedino na jugozapadu govornoga područja: "[...] i to radi kratkoće samo jednim, meni bližim, a na svem jugozapadu ovoga jezika jedinim u narodu poznatim imenom $\mathrm{h}$ è r v a t s k i m" (Mažuranić 1861[2]; dalje M: bilj. na str. 1). U Slovnici je 
nekoliko mjesta na kojima opisano stanje stvarī upućuje na širi opseg značenja etnonima Hèrvati i odgovarajućega pridjeva hèrvatski u Mažuranića ${ }^{1}$, ali takva mjesta treba razumjeti kao dokaz Mažuranićeva truda u pribavljanju ravnopravnosti imenu hrvatskom s imenom srpskim. Sve postaje jasnije ako se zna da još godine 1841. Mažuranić zajedno s Ljudevitom Gajem odlazi na teren u primorje u potragu za čakavskim i štokavskim jezičnim i književnim vrelima, a neovisno o dvojici ilirskih prvaka na isti put kreće i Karadžić s dvojicom Rusa (N. I. Nadeždinom i D. M. Knjaževičem). Do danas nisu sasvim osvijetljeni Mažuranićevi osobni kontakti s Karadžićem, ali se zna da je susretā dviju grupa putnika po Lici, Dalmaciji i na Cetinju, kod Njegoša, bilo. I Karadžića i Mažuranića intrigirala su nacionalna imena. ${ }^{2}$ Ilirsko ime za Mažuranića uključuje i hrvatski nacionalni identitet, pa je i to razlogom što se u priručniku u kojem se opisuje i propisuje naddijalektna norma odlučuje za naziv hrvatski jezik; "zapravo ilirci nikome nisu osporavali njegovu nacionalnu pripadnost" (Tafra 1993: 28), dok je, na drugoj strani, osjećanje srpskoga nacionalnog identiteta sprječavalo Karadžića prihvatiti ilirsko ime, odnosno priznati nacionalnu pripadnost drugima (to je osobito izraženo u postulatima iz članka Srbi svi i svuda objavljenog 1849. u kojem samo čakavcima priznaje da su Hrvati). Vjekoslav Babukić u Osnovi slovnice slavjanske narěčja ilirskoga (1836) hrvatski jezik dijeli na tri narječja - štokavsko, kajkavsko i čakavsko, a Mažuranić u Slovnici govori o dvama glavnim hrvatskim narječjima: "[...] hèrvatski jezik ima dva glavna narěčja: štokavsko i čakavsko [...]” (M: 14). Štokavsko je narječje bilo najraširenije i na njemu su već bile tiskane mnoge knjige. Mažuranić je dakle "vjeran sljedbenik štokavske, upravo novoštokavske ijekavske tradicije kod Hrvata” (Moguš 1978: 32), a čakavsko je narječje Mažuranić kao izvorni govornik najbolje znao i u njemu je vidio suvremenu potvrdu naglasne geneze propisivanoga štokavskog modela. Radilo se o počecima akcentoloških poredbenih istraživanja prozodijskih sustava u hrvatskim

1 "P a z i 2. Hèrvatski jezik-je ono narěčje slavensko, što-se govori u obostranoj Hèrvatskoj (austrijanskoj i turskoj), Slavoniji, Bosni, Hercegovini, Sèrbiji i Cèrnoj Gori, tere ga Sèrblji takodjer sèrbskim zovu. Hèrvatski-je dakle i sèrbski jednoga istoga naroda jedan isti jezik, imajući ova dva obćenitija imena kao proizvod dviuh glavnih něgdašnjih dèržavah ovoga naroda *)" (Mažuranić 1861[2]: 1).

2 "[...] i Fran Mažuranić potvrđuje da su Antun i Vuk, u stanovitom natjecateljskom duhu, za shvaćanje svoga imena htjeli naći potvrdu u tradicijskim našim sredinama, koje još nisu u ono vrijeme imale priliku da usvoje ideje svojih nacionalnih prethodnika, izmaklih daleko naprijed" (Strčić 1987: 164). 
narječjima pa se smatra da je Antun Mažuranić u hrvatskome jezikoslovlju utemeljio dijalektologiju. $^{3}$

\section{O PODRIJETLU NOVOŠTOKAVSKOGA ČETVERONAGLASNOG SUSTAVA}

Mažuranić misli kako bi bilo bolje da se u gramatikama i rječnicima bilježi isključivo čakavski akcent jer se može "čakavski accenat sasvim lahko i bez ikakve smetnje štokavski čitati, samo kad-je i količina nenaglašenih dugih slovakah naznačena" (M: Predgovor, str. IV). Na temelju neobrativosti akcenatskih prijelaza (okretati štokavski accenat na čakavski nije onako lahko kao naprotiv) Mažuranić zaključuje da je štokavska akcentuacija novija i da je nastala na starijoj čakavskoj, ali on ne drži čakavsko narječje za prahrvatski jezik. Pojašnjava kako stari naglasak zove čakavskim samo zato "što-se-je u onih Čakavacah, koji-su malo udaljeniji od Štokavacah, sasvim čist i nepoměšan sačuvao: ali taj isti stari naglasak-je òd česti i štokavski”" (M: bilj. na str. 24). Nalazeći se pred zagonetkom o akcenatskoj zajednici narječjā, pretpostavlja postojanje najstarijega (predhèrvatskoga i predsèrbskoga) naglasnoga sustava koji bi bio nekakav "obći štokavski accenat svih zemaljah od Dunaja pa dò-mora Jadranskoga” (M: bilj.na str. 24). Govori da starim naglaskom govore štokavci u Slavoniji uz Savu, da se stari naglasak čuje po Bosni, ali i u Crnoj Gori, u Barskoj nahiji Albanije, u Boki Kotorskoj, u okolici Dubrovnika, u istočnoj Srbiji (u tzv. resavskom narječju), što sve treba razumjeti kao područja rasprostranjenosti dvonaglasnoga sustava sa silaznim naglascima. Naime nazivajući novoštokavski sekundarni dugosilazni naglasak (koji je nastao metatonijom neoakuta) strogo hèrvatskim, očigledno je kako je bio svjestan da je treći stari naglasak (neoakut) važan stupanj u razvoju upravo zapadnih novoštokavskih govora, a starohrvatski je sustav s trima naglascima (koji se dalje razvija u dvonaglasni monotonijski) nazvao čakavskim samo zato što ga je čakavsko narječje bolje sačuvalo od štokavskoga narječja. Tako se u Mažuranićevu naučavanju jasno vide četiri stadija u razvoju hrvatskoga jezika: 1) stadij hrvatskoga prajezika kao dijela

U Slovnici nalazimo cijele rečenice paralelno naglašene čakavski i štokavski, npr. čak. Slūgä velî, dà-je vodä dobrä, äli dà-je vīnö böljē od-vodê. (M: 14) (tj. Slūgà velĩ, dä-je vodà dobrä, äli dä-je vīnö böljē od-vodẽ.), štok. Slûga vèlī, dä-je vòda dòbra, äli dä-je vîno böljē od vòdē. (M: 14) (tj. Slúga vèlī, dä-je vòda dòbra, äli dä-je víno böljē od vòdē.) 
praslavenskoga naglasnog sustava (hèrvatski jezik kao narěčje slavensko); 2) starohrvatski stadij čije stanje prikazuje čisti čakavski; 3) prijelazni stadij u kojemu se tronaglasni sustav pojednostavljuje u dvonaglasni, odnosno stadij u kojemu se odvija proces novoštokavizacije zbog težnje za uzmakom ili za udaljivanjem od izvora silaznih naglasaka; 4) novoštokavski stadij s četirima naglascima. Mažuranićev naziv čakavski nije shvatio (ili nije želio shvatiti) Daničić koji se u Prilogu za istoriju akcentuacije hrvatske ili srpske obrušio na Mažuranića: "Niti je štokavska akcentuacija postala od čakavske, ni čakavska od štokavske, nego obje od starije zajedničke [...]" (Daničić 1872: 232), a u naše vrijeme Mažuranića ne shvaća (ili ne želi shvatiti) Keipert koji tvrdi da je u Slovnici "u jezičnom materijalu koji se opisuje, u skladu sa širokim opsegom pojma hèrvatski jezik, očigledno povezano srpsko i hrvatsko" (Keipert 2014: 255). O podrijetlu štokavskoga četveronaglasnog sustava u Mažuranićevoj gramatici najbolje govori originalna Mažuranićeva misao o primarnome i sekundarnome silaznom naglasku te kontinuirano povezivanje raznolike dijalektne građe. Problem je Mažuraniću stvorilo to što kao izvorni čakavac nije suvereno vladao štokavskom akcentuacijom, a boraveći u Zagrebu bilo mu je, kako se očitovao u Predgovoru (str. V), teško pronaći informanta "koji-bi sasvim čisto budi štokavskim budi čakavskim accentom umio govoriti". Zato se, kada se o čakavskome naglasku radilo, ograničio samo na svoj vinodolski govor, dok je štokavski naglasak provjeravao u pisanim izvorima - i hrvatskim i srpskim. Poziva se na Kašićevu gramatiku, na rječnike - Della Bellin i Stullijev, a naravno da je pri svakoj dvojbi naglaske standardnoga govora koji se nazivao hercegovačkim (osobito kada je bilo riječi o fonološkim pitanjima) morao provjeravati u Karadžićevu Srpskom rječniku (1852[2]), u Daničićevoj Maloj srpskoj gramatici (1850) i akcentološkim raspravama (Nešto o srpskijem akcentima, 1851). Ipak u Mažuranićevoj naglasnoj teoriji ima pogrešaka: 1) Nigdje u Slovnici ne kazuje da se čakavski uzlazni naglasak ( ) razlikuje od novoštokavskoga dugouzlaznog naglaska (/) i oba ta naglaska bilježi cirkumfleksom (`). $\mathrm{Na}$ str. 13. kaže: "Ukupno su dakle četiri naglaska; dva za kratke, à dva za duge slovke. - U čakavskom su samo 3, jer neima slaboga težkoga." Dakle Mažuranić ističe kako čakavski govor nema kratkouzlaznoga naglaska, što je nepotpuna tvrdnja jer čisti čakavski govor nema ni dugouzlaznoga (/) naglaska. Opravdano je misliti da je Mažuranić kao rođeni čakavac znao izgovoriti neoakut, ali nije znao točno izgovoriti novoštokavski dugouzlazni naglasak (možda je čak mislio da su to isti naglasci). 2) Kada se ovjereni novoštokavski naglasak ne potvrđuje čakavskim korelatom u njegovu vinodolskom 
govoru, Mažuranić rekonstruira drugačiji stari hrvatski naglasak nazivajući ga čakavskim. Npr. vinodolski čakavski govor ima "krnje" infinitive na -t/-ć pa se ondje nisu mogli očuvati stari uzlazni naglasci u infinitivu kao pèći $(<$ *pećí), trésti ( $<*$ trēstï), nego je moglo biti samo pëć $i$ trẽst $>$ trêst. Međutim Mažuranić kaže: "Čakavski-je naglasak něgda bio: tūćî, dūbstî, zēbstî itd. ali ja-ga nisam nikada čuo; barem u Vinodolu-se sada govori: tûć, vûć, dûbst (i dûst) itd." (M: bilj. na str. 19). Iako gubljenje dočetnoga -i prema jednim akcentolozima jest (usp. Vukušić 1984), a prema drugima nije (usp. Kapović 2008) nužan preduvjet za nastanak naglasaka kao pëći i trêsti, činjenica je da je Mažuranić kod glagola propustio dokazati utjecaj dijalektnog ustrojstva na naglasni sustav jer se oslonio na pisane izvore. 3) U komparativnoj studiji iz 1860. Mažuranić je na temelju podudarnosti između čakavske i ruske akcentuacije pogrešno zaključio o početku procesa novoštokavizacije - smatrao je da je mlađe naglašavanje zamijenilo starije čakavsko doseljenjem Hrvata i Srba u sedmom stoljeću, što pak implicira da su stari Iliri bili također Slaveni, tj. "da se je ovdě već prije slavenski jezikom sa starim accentom govorilo" (Mažuranić 1860: 6). Išao je i dalje. Poredbena naglasna analiza bila mu je dokazom da stari Rusi govore nekadašnjim općim južnoslavenskim naglaskom, koji zbog njegove starine također zove čakavskim, pa čak i za to da se "ruski narod něgda iz Illiryka u Rusiju preselio" (isto: 7). Neodržive hipoteze o seobi Rusa s juga na sjever i o ruskoj akcentuaciji kao ishodištu Mažuranić nadilazi korektno prikazanim odnosom čakavskoga naglaska prema ruskomu naglasku u punoglasju u trima točkama: a) podudarnost zaosnovnoga naglaska, npr. čak. glāvä prema rus. головá, čak. srebrö prema rus. серебр́́; b) primjeri u kojima se iskonske dužine pod naglaskom pokraćuju (jer se radi o praslavenskom akutu), npr. čak. bläto prema rus. боло́то (*bőlto) i čak. kräva prema rus. kоро́ва (*kőrva) te primjeri u kojima se ruski naglasak kao oró ne pokraćuje (jer se radi o praslavenskom dugom neoakutu: $\sim$ ), npr. čak. krãlj (= kraälj) prema rus. коро́ль ( ${ }^{*}$ kõrlb), (gen. krāljä : короля́), c) primjeri u kojima se vidi odraz praslavenskoga dugog cirkumfleksa, npr. čak. zlâto (= zläato) prema rus. зо́лото. Navedeno pokazuje da je Mažuranić s velikim ambicijama pristupio obradi akcenatske problematike.

\section{OSNOVNE POSTAVKE OPISA NOVOŠTOKAVSKOGA NAGLASNOG SUSTAVA}

3.1. Nosilac naglaska je slog, tj. slovka, a isticanje jednoga sloga u riječi nad drugima naglasak riječi: "U rěčih se obično po jedna slovka jäče izgòvara 
nego li druge, pak onaj jači udarac glasa veli-se naglasak (accentus) [...]" (M: 10). "Naglasak-je ona sila glasa u jednoj slovci, koja òstale nenàglāšene slovke k sebi priteže [...]" (M: 10).

3.2. U jednoj riječi ne može biti više od jednoga naglaska: "Gdě ima više naglasakah, ono nije jedna rěč, nego-su dvě zlo skupa napisane: $\mathrm{C}$ è $\mathrm{r}$ $\mathrm{n}$ a g ò r a, N òvi s á d, S t à ri g r á d, k à k o g ò d, k ò j i g ò d; (a kao jedna rěč izgovaraju-se ove poslědnje kakògod, kojìgod) itd. město: Cèrna Gòra, Nòvi Sád, Stári Grád: kàko göd, kòji göd, itd." (M: 11). O duljim superlativima (5-7 slogova) Mažuranić govori kao o naglasnim skupovima u kojima je naglasak na nâj jači, tj. glavni, a kratkouzlazni na trećem slogu od kraja komparativa slabiji, pomoćni jer prvi naglasak "neima toliko sile, da-bi sám mogao sve ostale slovke dò kraja rěči ù kupu dèržati, nego-mu treba usred rěči još jedan slabiji naglasak ù pomoć, ter nastanu prividno dva [...], n. pr. ná j u č è n i j i, ná j p l e m e n ì t i j e m u" (M: 11). Govoreći o prividno dvama naglascima, Mažuranić je spoznao da naglasni skupovi u sklopu kojih se uspostavlja hijerarhija između glavnoga i sporednih naglasaka nisu karakteristični za hrvatski jezik, nego za strane jezike, npr. za njemački u kojem je $B$ "ürgerm'eister. U hrvatskome jeziku 'Naglasak-je znak jedne i samòstalne rěči, ter koliko naglasakah, onoliko ima samostalnih rěčih ù govoru" (M: 11$){ }^{4}$

3.3. U bilježenju naglasaka Mažuranić se oslanja na grčki prozodijski sustav. Nazive akut, cirkumfleks i gravis prilagodio je potrebama našega jezika i pridružio im vrijednosti prema hrvatskoj tradiciji obilježavanja prozodijskih jedinica koja počinje s Bartolom Kašićem. Akutom označava dugosilazni naglasak koji je dvostrukoga postanja: 1. iskonski dugosilazni - izvorni oštri, "koji-je već u čakavskom oštar: d á r, b ó g, t á b o r, s ú n c e, g lá v u itd." (M: 13); 2. noviji dugosilazni koji je nastao metatonijom neoakuta - noviji oštri, "strogo hèrvatski, koji-je iz čakavskoga zavinutoga po težnji za uzmakom nastao: b á n itd. (§. 40. b), k r á j, p í š e m, od bân, krâj, pî̌sem. (§. 40, c)" (M: 13). Cirkumfleksom označava dugouzlazni naglasak-zavinuti: g 1 â v a, p ê t a, v în o, B ô ž o, r û k a, r i è k a (M: 13) i spominje kako je Karadžić u svome rječniku zamijenio dva znaka za duge naglaske (oštri i zavinuti) protivno starijem običaju. Gravisom označava kratkouzlazni naglasak - slabi težki: v ò d a, n ò g a, g ò r a, ò t a c (M: 12). Za kratkosilazni naglasak - jaki težki - ima znak kakav i

4 Od novijih hrvatskih gramatika samo ona J. Silića i I. Pranjkovića (2005) nedvojbeno polazi od toga da u hrvatskome jeziku jedna naglasna jedinica ima samo jedan naglasak. 
danas upotrebljavamo: b r ä t, b r ä t a, k nj ì g a, k ö $1 \mathrm{o}$, ö $1 \mathrm{o}$ v o, g 1 ë d a t i (M: 11). Stari hrvatski pisci su se za označavanje kratka naglašena sloga služili suglasničkim geminatama (okko = öko), a Mažuranić je znak za kratkosilazni naglasak preuzeo od Karadžića. Za zanaglasnu dužinu ima znak kakav je i danas.

3.4. Mažuranićev se opis novoštokavskoga naglaska s fonološkoga stajališta podudara s opisima teoretičara mnogo desetljeća poslije. Uočio je da se dugi naglasci sastoje od dviju mora te da je kod silaznoga naglaska tonska silina na prvoj, a kod uzlaznoga na drugoj mori: "Ovi-su dakle naglasci (oštri i zavinuti) udaljeni jedan òd drugoga za pol slovke: glávu glâva = gläavu glaàva" (M: 13). Odnos između čakavskoga i novoštokavskoga narječja Mažuranić interpretira kao povlačenje iktusa na različitim razinama. Novoštokavsko pomicanje silaznih naglasaka događa se na razini sloga: 'Svaki čakavski naglasak (bio" ,' ili ^) u srědini i na kraju rěči prelazi u štokavskom za jednu slovku (syllabu) òd kraja, i to kao zavinuti, ako-je ona slovka u čakavskom duga, a kao slab težki, ako-je u čakavskom kratka; n. p. čak. glāvä, vodä, dobröta, neznàm, nedâm, štok.: glâva, vòda, dobròta, nèznām, nèdām" (M: 23). U čakavskim govorima tonski mogu oponirati samo dugi slogovi (s naglaskom ili ), a metatonija na dugom slogu (prijelaz $\sim^{\wedge}$ ) tumači se kao skakanje iktusa za jednu moru jer Mažuranić kaže da je noviji oštri (sekundarni dugosilazni naglasak) “iz čakavskoga zavinutoga po težnji za uzmakom nastao" (M: 13), tj. "Svaki-bo čakavski zavinuti naglasak uzmakne u štokavskom najprije za pol slovke natrag, i tim postane o š t a r u istoj slovci [...]" (M: 13), dakle bãn (= baän) > bân (= bäan) ${ }^{5}$

3.5. Što se fiziologije naglasaka tiče, Mažuraniću su za ostvaraj naglaska auditivno relevantna ponajprije prozodijska obilježja jačine i trajanja. On ne govori kao npr. Šime Starčević u svojoj gramatici (1812) da se glas diže ili pada. Za njega je uzlaznost slabiji udarac glasa. Također upozorava na iskustvenu pojavu da se u novoštokavskome sustavu uzlazni naglasci ostvaruju na različite načine. ${ }^{6}$ Tako za slabi težki, tj. kratkouzlazni naglasak kaže da je više dug negoli kratak, a da se u gradovima izgovara gotovo kao posve kratak: "Ovakvo-se raztezanje kratkih slovakah lasno opažuje

5 To objašnjenje potpuno odgovara Ivšićevu prema kojemu pĩta od *pītâ odgovara vrijednosti *piìtā (promjena naglaska koju Ivšić naziva skakanjem), a pítala od pītäla samo *piìtala (promjena naglaska koju Ivšić naziva pomicanjem) (v. Ivšić 1911: 136). Odnosno ã odgovara formuli aä, á odgovara formuli aà, a imamo li u nestegnutom liku äa, onda je u stegnutom liku uvijek â.

6 Prema Brozoviću (1954) u hrvatskoj se ortoepiji priznaje samo centralnoštokavski izgovor uzlaznih naglasaka. 
ù govoru Hèrvatah Štokavacah, živućih pò selih: ali po gradovih i varoših austrijanskih zemaljah našega jezika izgovaraju-se ovakve slovke skoro kao prave kratke tako, da često ni uvěžban sluh nemože razpoznati slabijega udarca glasa; pa ovaj kratji izgovor dèrže gradjani kao uljudniji” (M: bilj. na str. 12). Opetovano ističe problem s kojim se susreću izvorni čakavci hoteći govoriti novoštokavskim naglaskom, a koji proizlazi iz činjenice što čakavci kratkouzlaznoga naglaska nemaju pa ga, kaže Mažuranić, ne mogu ni izgovoriti: "[...] izgovaraju: göra, mägla, nöga, jëlên, sökol, tëmēlj; město: gòra, màgla, nòga, jèlēn, sòkol, tèmelj, itd, itd." (M: bilj. na str. 25) Pored naravne dužine samoglasnika ["Pravi po naravi dug (naturā longa) glasnik-je onaj, koji-se izgovara kao dva glasnika u jednoj slovci, n. p. aa, ee, ii, oo, uu, ie [...]"], uočio je položajnu dužinu koja je kratja od naravne, a javlja se ispred dvaju ili više suglasnika u riječima kao obski, lavski, skladno, kolni, parno, vedro: "[...] slovka takva veli-se p o 1 o ž a j e $\mathrm{m}$ t. j. sbog položaja duga (positione longa)" (M: 9).

3.6. Mažuranić je dao potpuna pravila o distribuciji naglasaka: u dvosložnih i višesložnih riječi nijedan naglasak ne može biti na posljednjem slogu, oštri i jaki težki mogu biti samo na prvom slogu, a slabi težki i zavinuti mogu biti na svakom slogu osim na posljednjem. Zanimljiva su Mažuranićeva opažanja o naglasku riječi posuđenih iz stranih jezika koja se podudaraju s Kravarevim postavkama teorije i prakse naglašavanja posuđenih riječi (usp. Kravar 1968). Mažuranić zaključuje dvoje: 1. U čakavskome se ne preinačuje naglasak riječi uzetih iz stranih jezika, nego je Isüs, apöstol, metánija (čit. metânija), āmên i āmîn (čit. āmẽn i āmĩn), farö portáre (čit. farö portâre), gerëcht, gewíss itd. (M: 25) 2. Iako je u novoštokavskome pomicanje naglaska izrazita pojava, to nekada nije moguće pa se npr. umjesto portáre, befrágen, gewésen (čit. portâre, befrâgen, gewêsen) ne može reći pòrtāre, bèfrāgen, gèwēsen, nego je portâre, befrâgen, gewêsen (čit. portáre, befrágen, gewésen) (M: 26), što znači da je naglasak preinačen na izvornome naglasnom mjestu. "Isto čini kadšto u tečaju govora i na početku rěči: zwei Tâge m. Táge (čitaj Táge umjesto Tâge, H. D.). Pa tako-se valjada dogodi i u hèrvatskih rěči: $\mathrm{m}$ ô $\mathrm{r} a \mathrm{~m}, \mathrm{v} \mathrm{r}$ i è $\mathrm{m}$ e (1. pad.), $\mathrm{m}$. móram, vrïeme (čitaj móram, vrijéme umjesto môram, vrijême, H. D.) [...]" (M: 26). Time Mažuranić potvrđuje metatoniju kao način naglasnoga usustavljivanja leksika koji je nastao u ranim fazama našega jezičnog razvoja spontanim naglasnim previranjem. ${ }^{7}$

7 Usp. tezu I. Škarića i sur. (1995) o metatoniji kao kabinetskom postupku za prilagodbu leksika. 
3.7. Mažuranić je dao pravila o skakanju naglaska na proklitiku (M: 22) te govori o gubljenju samostalnosti akcentogene riječi: "To-se razumě, da ona rěč, s koje naglasak skoči, izgubi samostalnost, te-se ona mora na svoj predlog itd. nasloniti, kao što-se predlog naslanja na onu, koja ostane samostalna" (M: 22). Dakle prema imanju/neimanju naglasaka Mažuranić razlikuje samostalne i nesamostalne rěči (atone). Enklitike je nazvao natražnim naslanjačama iliti natražnicama, a proklitike naprědnim naslanjačama iliti naprědnicama. Točno zaključuje kako samo oštri i jak težki (dakle oba silazna) skaču na proklitiku i kako rezultat ovisi o tome radi li se o izvornim ili novijim silaznim naglascima: nä zìd, pöd glāvu, ù dvōr, ù bārku, nà kuću, pö vodu... (M: 22). Jednakost naglaska u (novo)štokavskom i čakavskom narječju na prvim slogovima riječì može biti samo privremena jer čakavsko narječje oslabljenoga pomicanja naglaska na proklitiku nema: "n. p. čak. i štok. znäti, ülica, štok.: nèznati, nà ulicu (čak. neznäti, na ülicu)" (M 1860: 5). Zanimljivo je to što Mažuranić misli da je za pedagoške svrhe, dakle kada učenici u školama uče proklizu, dovoljno na proklitici bilježiti samo jedan znak, bez razlike je li ondje jak ili slab naglasak. Očigledno je bio svjestan da je prokliza problem novoga hrvatskoga naglašavanja i da je vrlo teško tumačiti akcentuaciju takvih primjera. Objašnjava kako, za razliku od čakavskoga, u štokavskome u nominativu jednine nije jasno značenje riječi lúg i súd (tj. lûg i sûd). Tek se u prijedložnome izrazu očituje različito značenje, npr. stäti nà sūd ('na posudu') i stäti nà sūd ('na sudište') (M: 15). ${ }^{8}$

\section{ZAKLJUČAK}

Iako je Mažuranić u predgovoru Slovnice istaknuo kako mu namjera nije bila upuštati-se u dublja iztraživanja o naravi naglaska, rezultat njegova truda je prvi veći opis naglasnoga sustava hrvatskoga standardnog jezika. Prethodio mu je onaj Šime Starčevića, pisca prve gramatike hrvatskoga jezika pisane hrvatskim jezikom (1812), kojemu također pripada važno mjesto u povijesti hrvatskoga naglašavanja jer je razlikovao četiri novoštokavska naglaska prije Karadžića i Daničića (v. Delaš 2012). Zajedničko je dvojici hrvatskih jezikoslovaca to što pri obradi naglasne problematike razlikuju razinu na kojoj

8 Tu opreku nalazimo u Dellabellinoj gramatici (1728): sûd ('giudizio') i súd ('vaso'), lûgh ('cenere') i lúgh ('bosco'); u Relkovićevoj gramatici (1767): sûd i sùd, lûg i lùg; u Babukićevoj gramatici (1836): lûg i lúg, sûd i súd. 
bi naglasak trebao funkcionirati kao standardni (razina njima suvremenoga nadregionalnoga idioma) od naglasne razine raznolikih dijalekata, a obojica se oslanjaju na novoštokavsku naglasnu tradiciju hrvatskih gramatičara i leksikografa. U Mažuranićevu se radu javlja novi moment - odnos prema prezentnom Karadžić-Daničićevu prozodijskom sustavu, potpuno istraženom i normiranom. Kao neizvorni štokavac na nekim se mjestima pokazuje slabim za Karadžić-Daničićeva naglasna rješenja, ali kontinuirano nastojeći novoštokavske naglasne likove potvrditi čakavskim naglasnim korelatima, dao je osnovu za uspostavljanje zapadnonovoštokavskih razvojno-objasnidbenih modela. Analiza osnovnih postavki Mažuranićeva opisa novoštokavskoga naglasnog sustava pokazala je da Mažuranićeva naglasna teorija vrijedi i danas, a budućim proučavanjima obličnoga naglaska Mažuranićeva naglasnog korpusa ostaje pokazati da je uspostavio naglasni sustav koji je podrijetlom, opsegom i domašajem u priopćajnoj praksi nedvojbeno zapadnonovoštokavski.

\section{LITERATURA}

Babukić, Vjekoslav. 1836. Osnova slovnice slavjanske narěčja ilirskoga. Zagreb.

Brozović, Dalibor. 1954. Akcentuacija tuđica na -or u hrvatskom jeziku. "Jezik", 3, 118-123.

Daničić, Đuro. 1872. Prilog za istoriju akcentuacije hrvatske ili srpske. "Rad JAZU", knj. 20, 150-233.

Delaš, Helena. 2012. Prozodija Šime Starčevića. Zagreb: Pergamena.

Della Bella, Ardelio. 1728. Istruzioni grammaticalli dellla lingua illirica. Dizionario Italiano, Latino, Illirico... Mleci.

Gopić, Josip. 1907. Prilog poznavanju akcenatske teorije Mažuranićeve u obziru na komentatorska domišljanja. Zagreb: Literarni klub akademičke mladosti Starčevićanske.

Ivšić, Stjepan. 1911. Prilog za slavenski akcenat. "Rad JAZU”, knj. 187, 133-208.

Kapović, Mate. 2008. Razvoj hrvatske akcentuacije. "Filologija”, 51, poseban otisak.

Katičić, Radoslav. 2008. Kulturnopovijesni kontekst Slovnice hrvatske Antuna Mažuranića, predgovor u: Mažuranić, Antun. 1859. Slovnica Hèrvatska. Za gimnazije i realne škole. Dio I. Rěčoslovje. Zagreb. Pretisak prvog izdanja: Institut za hrvatski jezik i jezikoslovlje. Zagreb. (Biblioteka Hrvatska jezična riznica: Pretisci; 7), 3-11.

Keipert, Helmult. 2014. Obzori preporoda. Kroatističke rasprave (prir. Tomislav Bogdan i Davor Dukić). Zagreb: FF-press.

Kravar, Miroslav. 1968. Problematika naše gradske akcentuacije. "Zadarska revija”, 17, 177-190. 
Mažuranić, Antun. 1860. O važnosti accenta hèrvatskoga za historiu Slavjanah. Programm des k. k. Gymnasiums zu Agram am Schlusse des Schuljahres 1860. Agram: National-Buchdruckerei des Dr. Ludwig Gaj. 3-7.

Mažuranić, Antun. 1861[2]. Slovnica Hèrvatska. Za gimnazije i realne škole. Dio I. Rěčoslovje. Zagreb.

Moguš, Milan. 1978. Antun Mažuranić. Zagreb: Zavod za znanost o književnosti Sveučilišna naklada Liber.

Relković, Matija Antun. 1767. Nova slavonska i nimacska grammatika-Neue Slavonische und Deutsche Grammatik. Zagreb.

Silić, Josip i Ivo Pranjković. 2005. Gramatika hrvatskoga jezika za gimnazije i visoka učilišta. Zagreb: Školska knjiga.

Starčević, Šime. 1812. Nòvà ricsôslovica ilìricskà, Trst. Pretisak prvog izdanja: Institut za hrvatski jezik i jezikoslovlje, Zagreb, 2002 (Biblioteka Pretisci; 2).

Strčić, Mirjana. 1987. Prilog poznavanju veza između Antuna Mažuranića i Vuka St.

Karadžića. "Historijski zbornik", 40, 1, 157-166.

Škarić, Ivo i sur. 1995. Kako se naglašavaju posuđenice. “Jezik”, 43, 129-138.

Tafra, Branka. 1993. Gramatika u Hrvata i Vjekoslav Babukić. Zagreb: Matica hrvatska.

Vukušić, Stjepan. 1984. Nacrt hrvatske naglasne norme na osnovi zapadnog dijalekta.

Pula: Istarska naklada.

\section{SUMMARY \\ ANTUN MAŽURANIĆ'S ACCENTUAL THEORY}

This article tries to provide support for standard Croatian accentual patterns by studying modern Stokavian accentual models in old Croatian grammar books, especially those published before the 1890s. Mažuranić's Slovnica is the first extensive description of the accentual patterns of standard Croatian, and it is therefore important to investigate the position of Mažuranić's accentology work in relation to the predominant Karadžić-Daničić prosodic system. In view of the fact that Mažuranić demonstrated the existence of a firm link between the Stokavian and Chakavian accents, it is shown that Mažuranić's idea of the foundation of the standard language as a superregional variety was not altogether in accordance with the school of thought established by Vuk Karadžić.

Key words: Croatian accentuation, Antun Mažuranić, grammar, standard Croatian 